Duthie, E. S. (1954). J. gen. Microbiol. 10, 427-436.

\title{
Evidence for Two Forms of Staphylococcal Coagulase
}

\author{
By E. S. DUTHIE \\ Royal South Hants Hospital, Southampton
}

SUMMARY: Staphylococci produce coagulase in two forms. One is bound to the cell wall and is responsible for the slide test. The other is liberated as free coagulase in the medium and is responsible for the tube test. Bound coagulase acts directly on the fibrinogen of certain animals which then causes clumping of the staphylococcal cells, while free coagulase acts on the 'prothrombin' of certain animals to give a thrombin-like product. Bound coagulase is antigenically distinct from free coagulase. It is released during autolysis and it can be used to produce specific antibodies in rabbits.

Two tests are now in use for the detection of staphylococcal coagulase in cultures. In the tube test, first described by Loeb (1903), the bacteria are grown in a sensitive plasma, which is usually diluted, for periods up to $24 \mathrm{hr}$.; coagulase production is then shown by the presence of a clot. A later development is the slide test (Much, 1908; Birch-Hirschfeld, 1934), which depends on the finding that when coagulase-positive staphylococci are emulsified in a sensitive plasma on a slide, thick clumps appear due to precipitation of the fibrinogen around the bacteria.

Cadness-Graves, Williams, Harper \& Miles (1943) made a large-scale comparison of the two tests and found a good correlation between them. Of $\mathbf{4 4 2}$ strains recovered from pathogenic conditions in humans, all but two gave both reactions. A further series obtained from wounds and nasal swabs showed more disagreement in that forty-eight strains were tube positive and slide negative, while three were tube negative and slide positive. Following this series, it was commonly assumed (Berger, 1943) that the two tests were measuring the same substance. Observations by Linsell \& Gorill (1951) threw some doubt on this assumption. They showed that plasma treated by heat or thiomersalate continued to give a positive slide test while losing its ability to give a positive tube test; no explanation was offered. In analysing the effect of heat on plasma it became clear that two coagulases were involved, one bound to the cells and giving the slide test, and one free in the medium and giving the tube test. These will now be referred to as bound and free coagulase, and evidence for their distinction will be presented.

\section{MATERIALS AND METHODS}

Free coagulase. The free coagulase was a lyophil dried preparation (16,000 M.c.D./mg.) from the 'Newman' strain of Staphylococcus aureus (Duthie \& Lorenz, 1952), and was normally used at a concentration of 0.5 or $1.0 \mathrm{mg}$. $/ \mathrm{ml}$. Tests were made by adding $0.2 \mathrm{ml}$. to $0.2 \mathrm{ml}$. of a suitable coagulable material in tubes $\mathbf{5 \cdot 0} \times \mathbf{0 . 8} \mathrm{cm}$. The tubes were held against a black background in a warm illuminated box, and tapped until a clot appeared, the 
time being measured. For times up to $3 \mathrm{~min}$. the reciprocal of the coagulase concentration plotted against the clotting time gave a straight line (Duthie, 1954).

Bound coagulase. Unless otherwise stated, the strain used was 'Newman', previously described as a good producer of free coagulase (Duthie \& Lorenz, 1952). The cells from shaken digest broth cultures were washed in saline and resuspended to a standard density $\left(4 \times 10^{9}\right.$ cells $/ \mathrm{ml}$.); $0.2 \mathrm{ml}$. of this suspension was added to $0.2 \mathrm{ml}$. of diluted plasma or to $0.2 \%$ bovine fibrinogen in $5.0 \times 0.8 \mathrm{~cm}$. tubes and shaken in a special rack in a Kahn shaker. Against a black background using direct lighting and a lens, the degree of clumping could be graded quantitatively and was recorded as,- tr.,,, \pm++ \pm or ++ .

Titration of antibody to bound coagulase and of inhibitor to this antibody. For antibody titration $\mathbf{0 . 1} \mathrm{ml}$. volumes of falling dilutions of antibody in saline were added to $\mathbf{0 . 1} \mathrm{ml}$. of a standard 'Newman' suspension and left for $30 \mathrm{~min}$. on the bench. One-tenth $\mathrm{ml}$. of $0.2 \%$ bovine fibrinogen was added, and after shaking in a Kahn shaker until the controls became positive (1-2 min.), the tubes were read as in the titration of bound coagulase. In the antibody inhibition test $0.1 \mathrm{ml}$. volumes of falling dilutions of antiserum (Wellcome Research Laboratories staphylococcal antiserum KCP 2029), usually in dilutions of $1 / 160$ to $1 / 500$, were added to $0.1 \mathrm{ml}$. volumes of the solutions to be tested for inhibitor. At the same time a control series containing saline instead of inhibitor was set up. The mixture was left for $30 \mathrm{~min}$. on the bench, $0.1 \mathrm{ml}$. of the standard suspension was then added and after mixing left for another $30 \mathrm{~min}$.; $0.1 \mathrm{ml}$. of bovine fibrinogen $0 \cdot 2 \%(\mathrm{w} / \mathrm{v})$ was then added, and after shaking until the control tubes were positive at 1/500 antiserum, the results were recorded as before.

Activator. This was measured by adding $0.1 \mathrm{ml}$. solution of free coagulase to a mixture of $0.1 \mathrm{ml}$. activator solution and $0.2 \mathrm{ml}$. of $0.4 \%(\mathrm{w} / \mathrm{v})$ bovine fibrinogen (Armour's Fraction I). Since clotting times plotted against the reciprocal of the activator dilution gave a straight line over a limited range, comparisons were possible.

Purified prothrombin. This was prepared from human plasma following the method of Jaques (1943). It was used at a strength of $1.0 \mathrm{mg} . / \mathrm{ml}$.

Crystalline trypsin. This contained approximately $\mathbf{5 0} \% \mathrm{MgSO}_{4}$, and was that used by Duthie \& Lorenz (1949), when it was assigned the arbitrary value of 20,000 units/mg.

\section{Differences between bound and free coagulase}

Effect of heat on plasma. The first indication of a difference between the two types of coagulase was given by the behaviour of heated plasma. Human or rabbit plasma diluted to $10 \%(\mathrm{v} / \mathrm{v})$ in saline and heated at $56^{\circ}$ for $4 \mathrm{~min}$. no longer clotted with free coagulase or with thrombin. Failure to clot with free coagulase was not due to loss of activator which was always $c .50 \%$ of the original. On the other hand, this heated plasma readily clumped the cells in the bound coagulase test, though more slowly and less strongly than did un- 
heated plasma. Plasma brought to $\mathrm{pH} 2$ and then neutralized behaved in the same way as heated plasma.

Mode of action of the two coagulases. As first shown by Smith \& Hale (1944), free coagulase will only clot guinea-pig plasma in the presence of an activator found in the plasmas of certain animals. Duthie \& Lorenz (1952) produced evidence to show that the activator is probably prothrombin; a typical experiment is shown in Table 1.

Table 1. Experiment to show that the action of free coagulase depends on the presence of a sensitive prothrombin or a closely related substance

All dilutions were made in saline.

$0 \cdot 2 \mathrm{ml}$. free coagulase $+0.2 \mathrm{ml}$. guinea-pig plasma $10 \%(\mathrm{v} / \mathrm{v})$

$0.2 \mathrm{ml}$. free coagulase $+0.2 \mathrm{ml}$. guinea-pig plasma $10 \%(\mathrm{v} / \mathrm{v})+0 \cdot 1 \mathrm{ml}$. human prothrombin purified

$0 \cdot 2 \mathrm{ml}$. free coagulase $+0.1 \mathrm{ml}$. human prothrombin purified

$0.2 \mathrm{ml}$. free coagulase $+0.2 \mathrm{ml}$. guinea-pig plasma $10 \%(\mathrm{v} / \mathrm{v})+0.2 \mathrm{ml}$. of $0 \cdot 2 \%(w / v)$ bovine fibrinogen

No clot

Rapid clot

No clot

No clot

Table 2. Experiment to show that the action of bound coagulase depends on the presence of a sensitive fibrinogen and not on an active prothrombin

(All dilutions made in saline.)

$0 \cdot 2 \mathrm{ml}$. washed cells $+0 \cdot 2 \mathrm{ml}$. guinea-pig plasma $10 \%(\mathrm{v} / \mathrm{v})$

$0 \cdot 2 \mathrm{ml}$. washed cells $+0.2 \mathrm{ml}$. guinea-pig plasma $10 \%(\mathrm{v} / \mathrm{v})+0 \cdot 1 \mathrm{ml}$. heated human prothrombin

Nil

$0.2 \mathrm{ml}$. washed cells $+0.2 \mathrm{ml}$. guinea-pig plasma $10 \%(\mathrm{v} / \mathrm{v})+0.1 \mathrm{ml}$. of $0.02 \%$
bovine fibrinogen

$0.2 \mathrm{ml}$. washed cells $+0.2 \mathrm{ml}$. guinea-pig plasma $10 \%(\mathrm{v} / \mathrm{v})+0.1 \mathrm{ml}$. of $0.02 \%$
bovine fibrinogen
$0.2 \mathrm{ml}$. washed cells $+0.2 \mathrm{ml}$. saline $+0.1 \mathrm{ml}$. of $0.02 \%(\mathrm{w} / \mathrm{v})$ bovine fibrinogen

Nil

Clump

Clump

By contrast washed cells representing bound coagulase will not clump in guinea-pig plasma, even when human prothrombin is added (Table 2). The purified prothrombin in this case was heated for $4 \mathrm{~min}$. at $60^{\circ}$ to denature small traces of human fibrinogen which are difficult to remove. The loss of activator by heating was again $c .50 \%$. Since the addition of a minute amount of bovine fibrinogen, which contained no activator, was sufficient to cause clumping there was no evidence of inhibitory action by the guinea-pig plasma. Similar results were obtained when freshly precipitated guinea-pig fibrinogen was used instead of guinea-pig plasma.

Species specificity of plasmas to the two coagulases. Species specificity of plasma to the action of bacterial toxins is well known in the case of streptokinase and free coagulase. It was therefore not surprising to find that certain plasmas, e.g. sheep and guinea-pig, were completely insusceptible to the action of bound coagulase, others, for example, cow and horse, occupied an intermediate position, while dog, mouse, human and rabbit plasmas were highly sensitive. Species differences for bound coagulase were best measured by finding the limiting dilution of plasma (plasma titre) sufficient, on prolonged shaking, to clump a given suspension of staphylococci when a highly active strain such as 'Newman' was used (Table 3). This was a measure of the sensitivity of the fibrinogen to bound coagulase and did not compare with the 
findings for free coagulase which depended on the sensitivity of the activator (prothrombin). Thus, of the eight plasmas listed only three, e.g. horse, human and rabbit, were good sources of activator and clotted readily with free coagulase, while all but guinea-pig and sheep contained fibrinogen which reacted readily with bound coagulase.

\section{Table 3. Comparison of plasmas of different animals as a source of activator for free coagulase and of fibrinogen for bound coagulase}

Activator test mixture was $0.1 \mathrm{ml}$. of $0.1 \%(\mathrm{w} / \mathrm{v})$ free coagulase $+0.2 \mathrm{ml}$. of $0.4 \%(\mathrm{w} / \mathrm{v})$ bovine fibrinogen $+0.1 \mathrm{ml}$. of $10 \%$ plasma. The plasma titre was that dilution of plasma causing perceptible clumping of the cell suspension on $10 \mathrm{~min}$. shaking.

$\begin{array}{lcc}\text { Plasma } & \begin{array}{c}\text { Clotting time using } \\ \text { plasma as activator } \\ \text { for free coagulase }\end{array} & \begin{array}{c}\text { Plasma titre for } \\ \text { bound coagulase }\end{array} \\ \text { Sheep } & >10 \mathrm{~min} . & \text { Nil } \\ \text { Guinea-pig } & >10 \mathrm{~min} . & \text { Nil } \\ \text { Cow } & >10 \mathrm{~min} . & 1 / 100 \\ \text { Horse } & 2 \mathrm{~min} . & 1 / 50 \\ \text { Dog } & >10 \mathrm{~min} . & 1 / 2000 \\ \text { Mouse } & >10 \mathrm{~min} . & 1 / 1000 \\ \text { Human } & 50 \mathrm{sec} . & 1 / 2000 \\ \text { Rabbit } & 40 \mathrm{sec} . & 1 / 2000\end{array}$

Strain differences in clumping with fibrinogen. Strains of staphylococci differed very much in their ability to clump in the presence of fibrinogen, and a rough measure was the limiting dilution of human plasma just sufficient to cause clumping. About twelve strains from various sources were compared, and it was found that they varied widely between those which gave titres of 1/30 for poor strains and two strains which gave good clumping at final dilutions of $1 / 4000$ of human plasma, corresponding to a final dilution of one part in three millions of fibrinogen. The two strains which gave these high titres were the best strains so far encountered for the production of free coagulase in the absence of albumin (Duthie, 1954). Later work showed that the plasma titre for clumping bore no relation to the amount of bound coagulase present on the cell surface. The phenomenon is under investigation.

Like free coagulase, bound coagulase was stable at $\mathrm{pH} 2$. The washed and acid-treated cells gave an even higher plasma titre than before, but this may have been due in part to their tendency to show some slight clumping in saline only. Living cells treated with crystalline trypsin rapidly lost their bound coagulase.

Apparent dissociation of the production of the two types of coagulase has been found in several strains isolated from routine nasal swabs, inasmuch as they produced large amounts of free coagulase in the presence of albumin but failed to clump when added to plasma or fibrinogen and shaken. This confirms the findings of Cadness-Graves et al. (1943). The converse has not yet been encountered.

Immunological specificity of the two coagulases. Antibodies to free coagulase have been found in the sera of normal humans (Lominski \& Roberts, 1946; Bekker, 1947; Tager \& Hales, 1948b; Rammelkamp, Hezebicks \& Dingle, 
1950; Duthie \& Lorenz, 1952). They have been produced experimentally in animals (Tager \& Hales, 1948 $a$; Rammelkamp, Badger, Dingle, Feller \& Hodges, 1949; Duthie \& Lorenz, 1952). These antibodies are specific for the free coagulase of different staphylococcal strains (Duthie, 1952). None of the antisera against free coagulase had any inhibitory action on bound coagulase. Certain commercial antisera made against the Wood $46 \alpha$-lysin inhibited bound but not free coagulase. The most satisfactory of these was a horse antiserum KCP 2029 made at the Wellcome Research Laboratories, Beckenham, and containing $400 \mathrm{u}$. $/ \mathrm{ml}$. of anti $\alpha$-lysin. Diluted $1 / 500$ this usually gave partial inhibition in the antibody test using the standard bound coagulase suspension (staphylococcal strain 'Newman') and complete inhibition at higher levels. A number of commercial non-staphylococcal equine antisera examined contained no antibody; small amounts were present in normal human sera and these will be investigated when the test is fully standardized. No antibody was found in normal animal sera, e.g. mouse, guinea-pig, rabbit, horse, sheep and cow.

\section{Identification and partial purification of bound coagulase liberated by autolysis}

Antibody inhibition test. Since the sera of horses immunized with staphylococcal toxoid made from cell-free filtrates of the Wood 46 strain contained an antibody to bound coagulase, it was likely that bound coagulase was liberated from these cells. Using the antibody inhibition test, described earlier, as a test for the presence of bound coagulase in cell-free culture material, no inhibitor was found in Wood 46 toxin or toxoid, or in broth cultures of several freshly grown staphylococcal strains. An inhibitor (later shown to be bound coagulase) was found in the supernatants of shaken broth cultures of coagulasepositive staphylococci which had been stored for several weeks at $4^{\circ}$ and which had undergone partial autolysis. The inhibitor was more easily detected if the cell-free supernatants were dialysed. Maximum amounts were present in supernatants of the 'Newman' strain, and a study of freshly grown cultures of this organism showed an increase when the flasks were left at room temperature. This was not associated with a gain in free coagulase (Table 4). The best yields were from cultures held between $\mathrm{pH} 6$ and 8.

Partial purification of bound coagulase. Since the inhibitory material was stable at $\mathrm{pH} 2$ it was easily concentrated and partially purified by precipitation with $\mathrm{CdSO}_{4}$ between $\mathrm{pH} 6$ and 7 , and the precipitate redissolved by the addition of $\mathrm{HCl}$ and dialysed against $0.01 \mathrm{M}-\mathrm{HCl}$. Such precipitates usually contained large amounts of free coagulase. In one culture which had undergone autolysis over a period of several months (Table 4) almost all the free coagulase, together with the remaining cells, was first removed by centrifuging at $\mathrm{pH}$ 3. More recently, the autolysis of washed cells at $4^{\circ}$ has provided material with good inhibitory power and which contained little or no free coagulase.

Properties of partially purified bound coagulase. Like free coagulase purified inhibitor was most stable in the acid range, and least in the alkaline (Table 5). It was also destroyed completely by crystalline trypsin, though not in the 
Table 4. Effect of ageing of broth cultures of staphylococcus strain 'Neroman' on liberation of an inhibitor, presumably bound coagulase, to bound coagulase antibody.

Cultures were grown to about $0.5 \times 10^{10}$ organisms $/ \mathrm{ml}$. left at rest, freed from cells, dialysed and tested at two-fold dilutions.

\begin{tabular}{|c|c|c|c|c|c|}
\hline \multirow[b]{2}{*}{ Age of culture } & \multicolumn{4}{|c|}{ Antiserum to bound coagulase } & \multirow{2}{*}{$\begin{array}{c}\text { Free } \\
\text { coagulase } \\
\text { (u./ml.) }\end{array}$} \\
\hline & $1 / 260$ & $1 / 400$ & $1 / 500$ & $\mathbf{0}$ & \\
\hline 4 months, $4^{\circ}$ & + & + & + & ++ & $<100$ \\
\hline 4 days, $20^{\circ}$ & - & \pm & ++ & ++ & 3000 \\
\hline 2 days, $20^{\circ}$ & - & \pm & + & ++ & 3000 \\
\hline 12 hr., $20^{\circ}$ & - & $\overline{-}$ & tr. & ++ & 5000 \\
\hline Broth control tube & - & - & \pm & ++ & - \\
\hline
\end{tabular}

$++=$ gross clumps; $+=$ moderate clumps; $\pm=$ faint clumps; tr. =very faint clumps; $-=$ no clumps.

presence of soya-bean trypsin inhibitor. In these respects it corresponded to bound coagulase when attached to the cells. The appearance of inhibitor in the broth supernatants of fully grown cultures left to autolyse was accompanied by a loss of bound coagulase from the cell surface. There was therefore strong presumptive evidence for regarding the inhibitory material as bound coagulase which had been liberated from the cell surface. The addition of this material when partially purified to purified human or bovine fibrinogen, caused no clotting in $1 \mathrm{hr}$., nor was there any evidence of digestion of the fibrinogen.

\section{Table 5. Stability of bound coagulase (inhibitor) after liberation from staphylococcal cells}

Dilutions of antiserum

$\overbrace{1 / 160 \quad 1 / 200 \quad 1 / 260 \quad 1 / 400 \quad \text { Saline }}$

Effect of suspension of staphylococci

1. Original inhibitor solution

2. After $48 \mathrm{hr}$. pH 2 room temp.

3. After $48 \mathrm{hr}$. $\mathrm{pH} 7$ room temp.

4. After $48 \mathrm{hr}$. pH 9 room temp.

5. Inhibitor + trypsin held $1 \mathrm{hr}$. pH $937^{\circ}$, then boiled .

6. Inhibitor + trypsin first boiled; then held $1 \mathrm{hr}$. pH $937^{\circ}$

7. Control: no inhibitor added

\begin{tabular}{|c|c|c|c|c|}
\hline \pm & $A$ & ++ & ++ & ++ \\
\hline+ & + \pm & ++ & ++ & ++ \\
\hline \pm & + & ++ & ++ & ++ \\
\hline tr. & \pm & + & ++ & ++ \\
\hline- & - & - & \pm & ++ \\
\hline \pm & + & ++ & ++ & ++ \\
\hline- & - & - & \pm & ++ \\
\hline
\end{tabular}

,$++ \pm=$ gross clumps; $+=$ moderate clumps; $\pm=$ faint clumps; tr. = very faint clumps; $-=$ no clumps.

Activity measured by its ability to inhibit antiserum to bound coagulase. Final concentration of trypsin $2 \times 10^{-4}(w / v)$.

Experimental antibody production. The supernatant broth from a culture of the 'Newman' strain which contained inhibitor was dialysed and boiled for $10 \mathrm{~min}$; this inhibitor was adsorbed almost completely by the addition of $2 \mathrm{mg}$. sterile $\mathrm{AlPO}_{4} / \mathrm{ml}$. A comparison was made of the immunizing properties of the adsorbed and unadsorbed material (Table 6). Normal rabbit sera 
showed no inhibition of bound coagulase. After three injections at weekly intervals, each consisting of adsorbed material from $3 \mathrm{ml}$. of the original broth, one rabbit serum showed partial inhibition at a titre of $1 / 32$ and the other at 1/16. Very much lower titres were obtained with culture fluid which had not been adsorbed on $\mathrm{AlPO}_{4}$ (Table 6). It was concluded that the supernatants of stored 'Newman' strain cultures contained bound coagulase, which had been liberated during autolysis.

Table 6. Production in rabbits of antibody to bound coagulase by use of the inhibitory material of Table 5 either unadsorbed or adsorbed on $\mathrm{AlPO}_{4}$. Injections given on 1 st, 7 th and 14 th days of the experiment

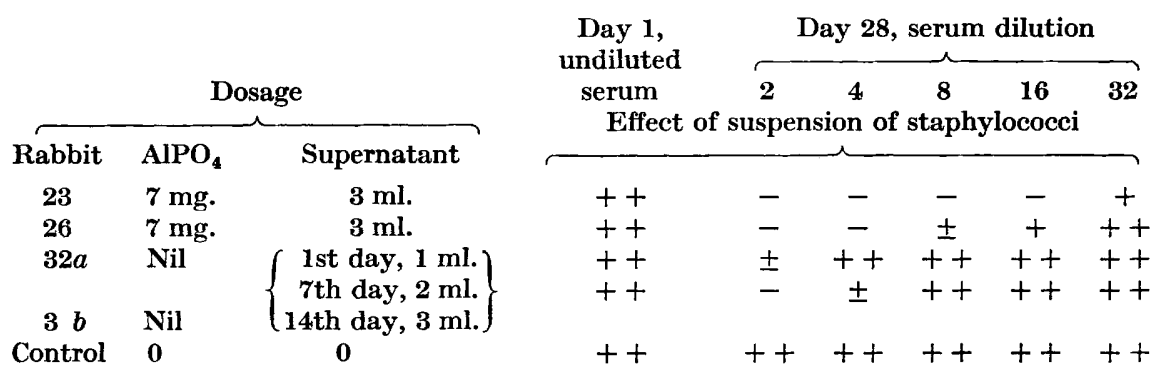

$++=$ gross clumps; $+=$ moderate clumps; $\pm=$ faint clumps; $-=$ no clumps.

\section{Comparison of the slide and tube tests}

A comparison of the slide test with the test used in the present work for bound coagulase, under varied conditions, showed no discrepancies. The slide test is therefore due to bound preformed coagulase on the cells. Under the conditions used by Linsell \& Gorrill (1951) this acts on plasma treated by heat or with thiomersalate and causes clumping of the cells.

By contrast the tube test requires the production of a clot, which is a function of free coagulase. Experiments have shown that even with a good coagulase-producing strain of staphylococci, insufficient free coagulase would be carried over in the inoculum used by Linsell \& Gorrill (1951); hence a positive result must be due to the production of free coagulase during the $2 \mathrm{hr}$. incubation period. This was of course impossible in the presence of 1/10,000 thiomersalate; the cells failed to grow and the test was negative. Tests of plasma treated with $1 / 10,000$ thiomersalate for $24 \mathrm{hr}$. have shown no loss of activator, and a minor change in the fibrinogen as indicated by a slight delay in the reaction when treated with bound coagulase, free coagulase or thrombin.

\section{DISCUSSION}

Proof of the separate identities of bound and free staphylococcal coagulase falls under three main headings; of these, the most important is mode of action. Free coagulase apparently acts on prothrombin or on some closely related substance and converts it to a thrombin-like product which will clot any fibrinogen. Bound coagulase, on the contrary, acts on a susceptible fibrinogen and alters it so that it precipitates on the staphylococci and causes 
them to clump. Both substances behave as proteins; free coagulase may be an enzyme since the conversion of prothrombin to a thrombin-like product by free coagulase follows an enzymic pattern (Miale, 1949; Duthie \& Lorenz, 1952). With bound coagulase prior incubation of the washed cells with minimal amounts of fibrinogen showed no shortening of the clumping time when the cells were agitated. Likewise, washed cells mixed with fibrinogen and removed immediately by centrifuging were just as strongly agglutinated as those left in contact with the fibrinogen for a longer time. The reaction may therefore be a stoichiometric one.

The second main point of difference lies in their different antigenic compositions; for many immunologists this would be conclusive. There is no known case of the same bacterial cell producing the same toxin in two different antigenic forms. Yet rabbit antisera against free coagulase failed to neutralize the bound coagulase on the cells from which the free coagulase had been obtained, and the antiserum KCP 2029 had no inhibitory action on free coagulase. Although antibodies to free coagulase are specific for the coagulase of certain staphylococcal strains, animal or human, present evidence suggests that the antibody for bound coagulase is non-specific.

The last point concerns the nature of the antibody inhibitor found in partially lysed broth cultures. The evidence so far accumulated suggests that this is originally bound coagulase which becomes liberated during autolysis. The strongest evidence for this is its ability to produce in rabbits antibody to bound coagulase. While the maximum amount of free coagulase was present at the end of growth, this inhibitory material did not appear in any quantity for several days. Separation of the two was possible in one culture tested by precipitation of the free coagulase and its removal with the cells by centrifuging at $\mathrm{pH} 3$ leaving the inhibitor free in the medium, or by autolysing washed cells. Like free coagulase it was stable in the acid $\mathrm{pH}$ range, and was partially purified by precipitation with cadmium, followed by dialysis in acid. This partially purified material had apparently no immediate action on fibrinogen when incubated with it; it is being further examined.

Besides Linsell \& Gorrill (1951) other authors have noted discrepancies in the behaviour of staphylococci as between slide and tube tests. BirchHirschfeld (1934) concluded that the slide test was caused by an agglutination of staphylococci by prothrombin and that the tube test was caused by a clotting of fibrinogen. Her conclusions are open to doubt, inasmuch as the fibrinogen solutions used contained prothrombin and the prothrombin solutions almost certainly contained denatured fibrinogen. In a survey of the slide test using plasmas and strains derived from different animals, Field \& Smith (1945) noted that negative slide tests were given by sheep and guineapig plasmas, in contrast to other plasmas which gave positive reactions. The addition of human sera to these insensitive plasmas failed to make them positive, as it should have done had the reaction been similar to that of the tube test. No attempt was made to explain the discrepancy between the two tests.

There are several references in the literature to an agglutination of streptococci by sera from patients suffering from acute bacterial infections (Weaver, 
1904; Tillett \& Abernethy, 1932). The reaction did not appear to be caused by specific antibodies but to a non-clottable protein which resembled fibrinogen (Tillett \& Garner, 1934). The latter authors showed that such strains of streptococci, when mixed with plasma or fibrinogen to dilutions as high as $1 / 40,000-1 / 80,000$ and incubated for $2 \mathrm{hr}$. at $37^{\circ}$, showed clumping when allowed to settle in the cold. There is thus a strong probability that streptococci produce a substance similar to the bound coagulase of staphylococci, and that the material in the sera of patients is a partly denatured fibrinogen similar to that obtained in the present study by acid or heat treatment of plasma.

From the survey of Cadness-Graves et al. (1943) it is clear that all pathogenic strains of staphylococci form free and bound coagulase. Strains which apparently produce only free coagulase are found occasionally in nasal and throat swabs and are of doubtful pathogenicity. As a consequence it would seem that the slide test alone is an adequate test for pathogenicity, and where there is doubt the organisms may be suspended in human plasma and shaken to see whether clumping occurs, a comparable saline suspension being used as a control. The tubes used in the present experiment are ideal for this purpose. The importance of these two coagulases in staphylococcal infections has yet to be determined. Hale \& Smith (1945) showed that free coagulase can produce in vitro a network of fibrin around leucocytes and thereby produce a mechanical obstacle to phagocytosis; they suggested that the same process may occur in vivo. There is as yet no proof that this happens in infections though Smith, Hale \& Smith (1947) reported greater virulence of staphylococci when injected in plasma which was coagulable by these bacteria. Rogers \& Tompsett (1952) showed that coagulase-negative staphylococci were destroyed following ingestion by phagocytes, but coagulase-positive strains survived and killed the leucocytes. This might be due to the ability of these strains to produce $\alpha$-lysin, but it is tempting to speculate that the presence of bound coagulase on the cell surface may hinder their being digested. A comparison of the survival of strains which produce $\alpha$-lysin or bound coagulase, but not both, might settle this point.*

I am grateful to Dr D. W. Henderson, Director of the Microbiological Research Department (Ministry of Supply), Porton, Wiltshire, for making available the facilities of his department for the production of coagulase. I wish to thank Dr R. A. Kekwick of the Lister Institute, London, for providing the specimens of fibrinogen and for very helpful advice, and the Wellcome Research Laboratories, Beckenham, Kent, for supplies of antiserum. I am also grateful to Miss J. Rowlands and Miss S. Isherwood for valuable technical assistance. The work was financed by a research grant from the South-West Metropolitan Regional Hospital Board.

\section{REFERENCES}

BekKer, J. H. (1947). Studies on staphylocoagulase. II. Antistaphylocoagulase in human serum. Leeuwenhoek ned. Tijdschr. 13, 128.

Berger, F. M. (1943). Clumping of pathogenic staphylococci in plasma. J. Path. Bact. 55, 435.

* The author now considers that the term 'clumping factor' is better than 'bound coagulase'. 
Birch-Hirschfeld, L. (1934). Über die Agglutination von Staphylokokken durch Bestandteile des Säugetierblutplasmas. Klin. Wschr. 13, 331.

Cadness-Graves, B., Williams, R., Harper, G. J. \& Miles, A. A. (1943). Slide test for coagulase positive staphylococci. Lancet, $\mathbf{i}, 736$.

Duthie, E. S. (1952). Variation in the antigenic composition of staphylococcal coagulase. J. gen. Microbiol. 7, 320.

Duthie, E. S. (1954). The production of free staphylococcal coagulase. J. gen. Microbiol. 10, 437.

Duthie, E. S. \& Lorenz, L. (1949). Protease inhibitors. I. Assay and nature of serum antiprotease. Biochem. J. 44, 167.

Duthie, E. S. \& Lonenz, L. (1952). Staphylococcal coagulase: mode of action and antigenicity. J. gen. Microbiol. 6, 95.

Field, H. I. \& Smith, H. W. (1945). Coagulase test for staphylococci. J. comp. Path. 55, 63.

Hale, J. H. \& Smith, W. (1945). The influence of coagulase on the phagocytosis of staphylococci. Brit. J. exp. Path. 26, 209.

J AQUES, L. B. (1943). The reducing properties of fibrinogen. Biochem. J. 37, 344.

Linsel, W. D. \& Gorill, R. H. (1951). The effect of heat and sodium ethyl mercurithio-salicylate on the staphylocoagulase test. J. clin. Path. 4, 73.

LoEB, L. (1903). The influence of certain bacteria on the coagulation of the blood. J. med. Res. 10, 407.

Lominski, I. \& Roberts, G. B. (1946). A substance in human serum inhibiting staphylocoagulase. J. Path. Bact. 58, 187.

Miale, J. B. (1949). The role of staphylocoagulase in blood coagulation. I. The reaction of staphylocoagulase with coagulase-globulin (CG) to form coagulasethrombin (CT). Blood, 4, 1039.

Much, H. (1908). Über eine Vorstufe des Fibrinfermentes in Kulturen von Staphylokokkus aureus. Biochem. Z. 14, 143.

Rammelkamp, C. H., Badger, G. F., Dingle, J. H., Feller, A. E. \& Hodges, R. G. (1949). A quantitative method for measuring staphylococcal anticoagulase. Proc. Soc. exp. Biol., N.Y., 72, 210.

Rammelkamp, C. H., Hezebicks, M. M. \& Dingle, J. H. (1950). Specific coagulase of Staphylococcus aureus. J. exp. Med. 91, 295.

Rogers, D. E. \& TOMPSETT, R. (1952). The survival of staphylococi within human leukocytes. J. exp. Med. 95, 209.

Smith, W. \& HaLe, J. H. (1944). The nature and mode of action of staphylococcus coagulase. Brit. J. exp. Path. 25, 101.

Smith, W., Hale, J. H. \& Smith, M. M. (1947). The role of coagulase in staphylococcal infections. Brit. J. exp. Path. 28, 57.

TAger, M. \& Hales, H. (1948a). Studies on the coagulase-reacting factor. II. Properties of coagulase reacting factor and relation to blood-clotting components. J. Immunol. 60, 1.

TAGer, M. \& Hales, H. (1948b). Differences in the resistance of human plasmas to staphylocoagulase. Yale J. Biol. Med. 21, 91.

TilletT, W. S. \& Abernethy, T. J. (1932). Serological reactions with haemolytic streptococci in acute bacterial infections. Johns Hopk. Hosp. Bull. 50, 270.

TilletT, W. S. \& Garner, R. L. (1934). The agglutination of haemolytic streptococci by plasma and fibrinogen. A comparison of the phenomenon to serological reactions with the same organism. Johns Hopk. Hosp. Bull. 54, 145.

Weaver, G. H. (1904). Agglutination of streptococci, especially those cultivated from cases of scarlatina by human sera. J. infect. Dis. 1, 91 . 